\title{
Pengaruh Motif Penggunaan Media dan Kualitas Informasi Terhadap Kepuasan Pembaca Detikcom
}

\author{
Elsa Susanto, Rezi Erdiansyah \\ elsasusantoo@gmail.com,Rezie@fikom.untar.ac.id \\ Fakultas Ilmu Komunikasi Universitas Tarumanagara
}

\begin{abstract}
This research discusses the influence of motives and information quality on reader satisfaction. This research uses the uses and gratification theory, motives, information quality and reader satisfaction. Detikcom is a web portal that contains online articles in Indonesia. The approach used for this research is a quantitative approach by using survey method. The population in this research is the downloader of detikcom and the number of samples taken is 100 people and uses the nonprobability sampling technique by using a purposive sampling approach. In this research, the data collected by using questionnaire. Based on the results of this research, the results obtained that partially or simultaneously, the motives and the quality of information affect the readers satisfaction. In the motive variable, the dimension of information motive is the most dimension that chosen by respondents while in the variable quality of information, the news relevance dimension is the most dimension that chosen by respondents. The variables that have more influence on reader satisfaction are information quality variable. The percentage of satisfaction obtained by respondents in the research of detikcom was $74.23 \%$.
\end{abstract}

Keywords: Motives, information quality, online news, satisfaction

\begin{abstract}
Abstrak
Penelitian ini dilakukan untuk mengetahui pengaruh motif dan kualitas informasi terhadap kepuasan pembaca Detikcom. Penelitian ini menggunakan teori uses and gratification, motif penggunaan media, kualitas informasi dan kepuasan. Detikcom adalah sebuah portal web yang berisi artikel online di Indonesia. Pendekatan yang digunakan untuk penelitian ini adalah pendekatan kuantitatif dengan metode survei. Populasi dalam penelitian ini adalah pengunduh detikcom dan jumlah sampel yang diambil sebanyak 100 orang dan menggunakan teknik nonprobability sampling dengan pendekatan purposive sampling. Data yang dikumpulkan dalam penelitian ini denggan menggunakan kuesioner. Berdasarkan hasil penelitian, maka diperoleh hasil bahwa secara parsial atau simultan, motif dan kualitas informasi berpengaruh terhadap kepuasan pembaca detikcom. Pada dimensi motif, indikator motif informasi merupakan indikator yang paling banyak dipilih oleh responden sedangkan pada dimensi kualitas informasi, indikator relevansi berita merupakan indikator yang paling banyak dipilih oleh responden. Variabel yang lebih berpengaruh terhadap kepuasan merupakan variabel kualitas informasi. Persentase kepuasan yang didapatkan responden dalam penelitian terhadap detikcom adalah sebesar 74,23\%.
\end{abstract}

Kata kunci: motif , kualitas informasi, berita online, kepuasan

\section{Pendahuluan}

Perkembangan teknologi di era modern ini memberikan banyak manfaat dalam berbagai aspek kehidupan manusia. Salah satu teknologi yang berkembang saat ini adalah internet. Internet adalah suatu jaringan komunikasi global yang 
menghubungkan seluruh jaringan komputer yang ada di dunia. Dengan hadirnya internet memberikan banyak kemudahan bagi setiap individu, seperti misalnya dalam hal mengakses informasi dan melakukan proses komunikasi. Komunikasi merupakan hal yang penting bagi manusia. Menurut Cutlip, Center dan Broom dalam (Azeharie dan kusuma, 2014), internet menyebabkan perubahan komunikasi yang sangat luas dan mendalam. Contoh bentuk komunikasi yang dilakukan oleh manusia adalah dengan cara bertukar informasi.

Informasi merupakan hal yang penting untuk menambah pengetahuan. Pentingnya informasi tersebut mendorong setiap individu untuk mencari tahu media mana yang paling efektif dan akurat. Untuk mendapatkan informasi tersebut, setiap individu dapat mengakses berita baik secara online maupun cetak. Pada zaman dahulu, berita hanya dapat diakses melalui media cetak seperti koran atau majalah, Namun seiring dengan berkembangnya zaman dan teknologi yang berkembang pesat, manusia menjadi lebih mudah untuk mengakses informasi yang terdapat dalam berita. Berita tesebut tersebut dapat diakses melalui portal berita online.

Dengan adanya portal berita online memberikan banyak sekali manfaat, salah satunya adalah manusia menjadi lebih mudah untuk mengakses berita kapan pun dan dimanapun melalui smartphone yang mereka miliki. Terdapat beberapa portal berita online yang ada di Indonesia, salah satu portal berita online tersebut adalah detikcom. Detikcom merupakan suatu portal web yang berisi berita dan dan artikel online di Indonesia. Detikcom merupakan salah satu situs berita terpopuler di Indonesia. Menurut survey, detikcom menempati posisi kelima di Indonesia.

Individu membaca berita karena terdapat beberapa dorongan yang mendorong setiap individu untuk membaca berita, dorongan tersebut dalam teori uses and gratifications disebut motif. Motif merupakan suatu pengertian yang meliputi semua penggerak, alasan-alasan atau dorongan-dorongan dalam diri manusia yang menyebabkan manusia melakukan sesuatu. Pembaca berita akan memilih dan membaca berita yang memiliki kualitas informasi yang baik. Menurut Goeth dan Davis (dalam Tjiptono, 2012). Kualitas informasi yang baik dapat berpengaruh terhadap kepuasan pembacanya.

Penelitian ini menggunakan variabel motif penggunaan media, kualitas informasi dan kepuasan pembaca detikcom sebagai objek karena motif merupakan salah satu unsur yang mendorong seseorang untuk membaca sebuah berita. Dalam membaca berita, setiap pembaca akan memilih portal berita yang memiliki kualitas informasi yang baik. Untuk mencapai kepuasan dan agar kebutuhan-kebutuhan pembaca terpenuhi. Sedangkan subjek dalam penelitian ini adalah detikcom, yang melatar belakangi penulis memilih detikcom karena detikcom merupakan portal berita online yang pertama di Indonesia. Berdasarkan latar belakang di atas, penulis tertarik untuk melakukan penelitian yang berjudul "Pengaruh Motif Penggunaan Media dan Kualitas Informasi Terhadap Kepuasan Pembaca Detikcom”.

\section{Motif Penggunaan Media}

Motif merupakan dorongan yang ada dalam diri manusia yang menyebabkan manusia melakukan sesuatu (Gerungan, 1983). Terdapat empat motif yang mendorong seseorang untuk mengkonsumsi media, keempat motif tersebut adalah motif informasi, motif indentitas pribadi, motif integrasi dan indentitas sosial, dan motif hiburan. 


\section{Kualitas Informasi}

Kualitas informasi adalah tingkat dimana informasi memiliki nilai bagi penggunanya. (O’Briens, 2005). Menurut Sutabri (2012) kualitas dari sebuah berita atau informasi yang baik bergantung pada tiga hal yaitu akurat (keakuratan berita), tepat waktu (ketepatan waktu detikcom dalam mengunggah sebuah berita) dan relevan (relevansi berita).

\section{Kepuasan}

Menurut Umar (2005) kepuasan adalah tingkat perasaan konsumen setelah membandingkan antara apa yang ia dapatkan dengan harapan-harapannyanya. Terdapat tiga indikator kepuasan menurut Hawkins dan Lonney yang dikutip Tjiptono (2015) dalam bukunya yang berjudul Strategi Pemasaran, ketiga indikator tersebut yaitu, kesesuaian harapan, minat menggunakan kembali, dan kesediaan merekomendasikan.

\section{Metode Penelitian}

Penelitian ini bertujuan untuk mengetahui pengaruh motif penggunaan media dan kualitas informasi terhadap kepuasan pembaca detikcom.

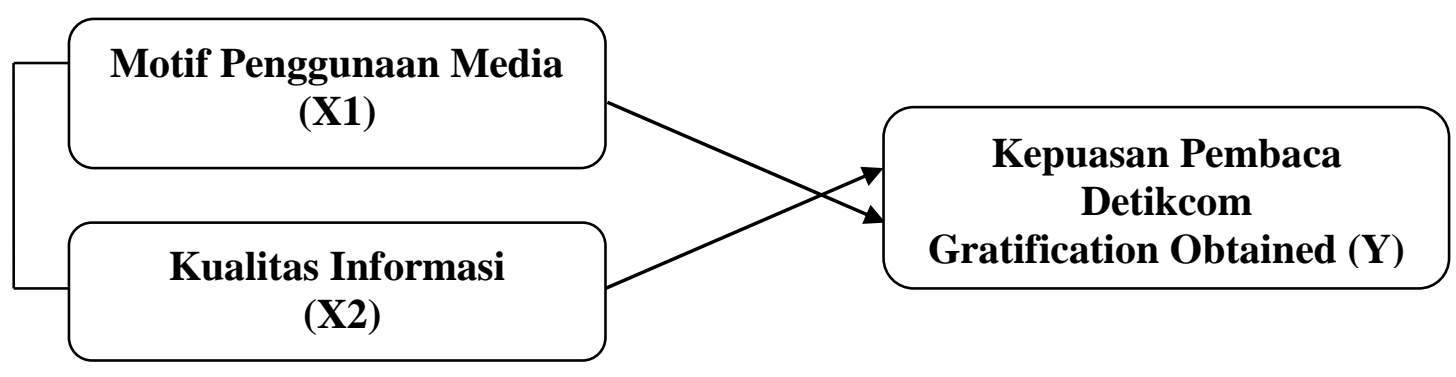

Dalam penelitian ini, penulis menggunakan metode penelitian kuantitatif dengan pendekatan survey. Metode survey adalah penelitian yang dilakukan dengan menggunakan angket sebagai penelitian (Sugiyono, 2013). Pada penelitian ini, populasi yang digunakan adalah pembaca Detik.com. Berdasarkan data yang didapatkan melalui google play store Detik.com diunduh sebanyak 10,000,000+ orang atau pengguna. Sampel yang akan digunakan dalam penelitian ini adalah sebanyak 100 responden.

Pengumpulan sampel dalam penelitian ini dengan menggunakan teknik non probability sampling dengan pendekatan purposive sampling. Data dikumpulkan dengan penyebaran kuesioner dengan menggunakan skala likert. Data primer dalam penelitian ini diperoleh melalui penyebaran kuesioner. Sedangkan data sekunder didapat melalui membaca buku-buku dan internet sebagai referensi.

Untuk mengetahui keabsahan data dalam penelitian ini, penulis menggunakan uji validitas, uji reliabilitas dan uji normalitas. Sedangkan untuk pengolahan data dalam penelitian ini, penulis menggunakan uji koefisien korelasi berganda, uji koefisien determinasi, uji regresi linear berganda, uji $\mathrm{T}$ dan uji F. Hipotesa dalam penelitian ini adalah sebagai berikut:

Hal: Terdapat pengaruh motif penggunaan media terhadap kepuasan pembaca detikcom.

Ho1: Tidak terdapat pengaruh motif penggunaan media terhadap kepuasan pembaca detikcom. 
$\mathrm{Ha}_{2}$ : Terdapat pengaruh kualitas informasi terhadap kepuasan pembaca detikcom.

$\mathrm{Ho}_{2}$ : Tidak terdapat pengaruh antara kualitas informasi terhadap kepuasan pembaca detikcom.

Ha3: Terdapat pengaruh motif penggunaan media dan kualitas informasi terhadap kepuasan pembaca detikcom

Ho3: Tidak terdapat pengaruh motif penggunaan media dan kualitas informasi terhadap kepuasan pembaca detikcom

\section{Hasil Temuan dan Diskusi}

Uji Validitas

Uji validitas digunakan untuk melihat apakah data yang didapatkan valid atau tidak. Dalam penelitian ini, penulis memiliki 20 pertanyaan yang diuji, penulis menyebarkan kuesioner pada 100 responden. Setelah data didapatkan, penulis mengolah data tersebut dengan menggunakan SPSS ver. 19 dan hasil yang penulis dapatkan dinyatakan valid karena $r$ hitung lebih besar dari 0,2 ( $\mathrm{r}$ tabel).

\section{Uji Reliabilitas}

Setelah diuji menggunakan SPSS, hasil cronbach's alpha untuk variabel motif penggunaan media (X1) sebesar 0,748. untuk variabel kualitas informasi (X2) didapatkan hasil cronbach's alpha sebesar 0,797 dan untuk variabel kepuasan (Y) didapatkan hasil cronbach's alpha sebesar 0,791. Berdasarkan hasil diatas maka dinyatakan bahwa data dari penelitian ini reliabel karena $r$ hitung yang didapatkan $>r$ tabel $(0,70)$.

\section{Uji Normalitas}

Uji normalitas merupakan sebuah pengukuran yang bertujuan untuk menilai sebuah data pada sebuah variabel, apakah normal atau tidak. (Nisfiannoor, 2013). Hasil dari penelitian ini didapatkan nilai signifikansi sebesar 0,661. Data dalam penelitian ini dinyatakan normal karena nilai signifikasi lebih besar dari 0,05.

\section{Uji Koefisien Korelasi Berganda}

Uji koefisien korelasi berganda adalah analisis yang digunakan untuk mengetahui seberapa kuat hubungan antara variabel $\mathrm{X}_{1}, \mathrm{X}_{2}$ dan $\mathrm{Y}$. Berdasarkan hasil uji koefisien korelasi diketahui bahwa koefisien korelasi (r) dari variabel $\mathrm{X}_{1}, \mathrm{X}_{2}$ dan Y dalam penelitian ini sebesar 0,713. Berdasarkan nilai interpretasi koefisien korelasi yang dikemukan oleh Sugiyono, maka dapat dinyatakan bahwa hubungan antara motif (X1), Kualitas Informasi (X2) dan kepuasan (Y) adalah kuat.

\section{Uji Koefisien Determinasi}

Uji koefisien determinasi $\left(\mathrm{R}_{2}\right)$ merupakan alat untuk mengukur seberapa besar kemampuan variabel X mempengaruhi variabel Y (Ghozali 2012). Hasil dari R square yang didapat adalah 0,509 sama dengan 50,9\% yang artinya variabel $\mathrm{X} 1$ dan $\mathrm{X} 2$ berpengaruh terhadap variabel Y sebesar 50,9\% . dari angka tersebut maka dapat disimpulkan bahwa pengaruh antara variabel bebas dan variabel terikat terbilang sedang. 


\section{Uji Regresi Linear Berganda}

Persamaan regresi linear berganda yang didapatkan dalam penelitian ini adalah $\mathrm{Y}=3,656+0,247 \mathrm{X} 1+0,515 \mathrm{X} 2$. Nilai 0,247 merupakan koefisien regresi dari variabel motif penggunaan media yang menunjukan bahwa setiap ada penambahan 1 nilai atau angka untuk variabel motif akan terdapat kenaikan kepuasan pembaca detikcom sebesar 0,247. Hal ini menunjukkan semakin besar nilai variabel X maka akan semakin mempengaruhi kenaikan nilai Y.

Nilai 0,515 merupakan koefisien regresi dari variabel Kualitas Informasi yang menunjukan bahwa setiap ada penambahan 1 nilai atau angka untuk variabel kualitas informasi akan terdapat kenaikan kepuasan pembaca detikcom sebesar 0,515. Hal ini menunjukkan semakin besar nilai variabel $\mathrm{X}$ maka akan semakin mempengaruhi kenaikan nilai Y.

\section{Uji T}

Uji $\mathrm{T}$ digunakan untuk pengaruh dari masing-masing variable $\mathrm{X}$ terhadap variabel Y (Sugiyono, 2017). Berdasarkan hasil uji T didapatkan angka untuk T hitung untuk variabel motif adalah sebesar 4,376 dan $\mathrm{T}$ hitung untuk variabel Kualitas informasi adalah sebesar 6,468. Nilai $\mathrm{T}$ tabel untuk penelitian ini adalah 1,988. Karena $\mathrm{T}$ hitung lebih besar dari $\mathrm{T}$ tabel, maka dapat disimpulkan bahwa motif dan kualitas informasi secara parsial berpengaruh terhadap kepuasan pembaca detikcom.

\section{Uji F}

Uji $\mathrm{F}$ digunakan untuk menguji pengaruh variabel bebas terhadap variabel terkait secara Bersama- sama atau simultan. (Sugiyono, 2017). Berdasarkan hasil perhitungan SPSS didapatkan nilai sig. Sebesar 0,000 yang berarti apabila sig $<0,05$ maka Ha diterima. Berarti variabel X1 dan X2 berpengaruh signifikan secara bersama-sama terhadap variabel Y.

\section{Pembahasan}

Penelitian yang penulis teliti menggunakan 3 variabel, yaitu variabel Motif Penggunaan Media (X1) dan variabel Kualitas Informasi (X2), yang merupakan variabel independent (bebas), serta variabel Kepuasan Pembaca (Y) yang merupakan variabel dependent (terikat). Penelitian ini menggunakan metode kuantitatif dan menggunakan kuesioner sebagai instrument pengumpulan data yang bertujuan untuk melihat seberapa besar pengaruh motif penggunaan media dan kualitas informasi terhadap kepuasan pembaca detikcom.

Berdasarkan hasil dari uji validitas, terdapat 20 butir pernyataan pada penelitian ini dan dinyatakan valid karena nilai corrected item total correlation > 0,2. Berdasarkan hasil uji reliabilitas pada masing-masing butir pernyataan variabel motif penggunaan media, variabel kualitas informasi dan kepuasan pembaca dinyatakan reliabel karena nilai cronbach's alpha $>0,7$. Berdasarkan hasil uji normalitas pada masing-masing butir pernyataan variabel motif penggunaan media, variabel kualitas informasi dan kepuasan pembaca dinyatakan normal karena nilai signifikasi $>0,05$.

Berdasarkan uji koefisien korelasi maka dapat dibuktikan bahwa hubungan antara ketiga variabel ini adalah kuat dan berdasarkan uji koefisien determinasi didapatkan angka sebesar 50,9\% yang artinya sebesar 50,9\% variabel motif penggunaan media dan kualitas informasi dapat memberikan informasi yang dibutuhkan variabel kepuasan pembaca. 
Hasil dari uji regresi linear berganda, terdapat persamaan $Y=3,656+0,247$ $\mathrm{X} 1+0,515 \mathrm{X} 2.3,656$ merupakan nilai konstanta yang menunjukkan bahwa apabila variabel motif dan kualitas informasi tidak mengalami perubahan maka, kepuasan pembaca akan mencapai 3,656. Nilai 0,247 adalah koefisien regresi yang menunjukan apabila terjadi perubahan atau penambahan 1 satuan untuk motif penggunaan media maka terjadi kenaikan sebesar 0,247 satuan pada kepuasan pembaca detikcom. Sedangkan nilai 0,515 merupakan koefisien regresi yang menunjukan apabila terjadi perubahan atau penambahan 1 satuan untuk kualitas informasi maka terjadi kenaikan sebesar 0,515 satuan pada kepuasan pembaca detikcom. Dapat disimpulkan bahwa apabila motif penggunaan media dan kualitas informasi ditingkatkan maka kepuasan pembaca detikcom juga akan meningkat atau sebaliknya.

Berdasarkan hasil uji T menunjukkan bahwa variabel motif penggunaan media memiliki pengaruh terhadap kepuasan pembaca (Y). Dapat dilihat juga pada variabel motif, motif informasi merupakan dimensi tertinggi yang mendorong responden dalam penelitian ini untuk membaca detikcom. Dan variabel kualitas informasi (X2) juga berpengaruh terhadap kepuasan pembaca (Y). Pada variabel Kualitas informasi, relevan merupakan dimensi tertinggi. Responden dari penelitian ini merasa informasi yang diberikan oleh detikcom adalah informasi yang relevan (bermanfaat dan sesuai dengan kebutuhan pembacanya).

Hasil uji $\mathrm{F}$ digunakan untuk melihat pengaruh variabel bebas terhadap variabel terikat secara serentak atau bersama-sama. Uji $\mathrm{F}$ dalam penelitian ini mendapat nilai signifikansi sebesar 0,000 yang berarti hasil tersebut lebih kecil dari 0,05 dan dapat disimpulkan bahwa terdapat pengaruh signifikansi anatar variabel bebas dan variabel terikat.

Berdasarkan hasil analisis dan pembahasan di atas, disimpulkan bahwa tingkat kepuasan yang didapatkan oleh pembaca detikcom dalam penelitian ini adalah sebesar 74,23\%. Motif penggunaan media dan kualitas informasi mempunyai pengaruh terhadap kepuasan pembaca detikcom, baik berpengaruh secara parsial dan simultan. Selain itu hubungan antara motif penggunaan media, kualitas informasi dan kepuasan pembaca detikcom adalah kuat, serta kemampuan motif penggunaan media dan kualitas informasi dalam mempengaruhi kepuasan pembaca detikcom sebesar $50,9 \%$.

\section{Simpulan}

Berdasarkan hasil penelitian yang dilakukan maka dapat disimpulkan bahwa motif penggunaan media dan kualitas informasi berpengaruh terhadap kepuasan pembaca detikcom secara parsial dan simultan. Motif dan kualitas informasi berpengaruh sebesar 50,9 \% terhadap kepuasan pembaca detik.com. Variabel kualitas informasi merupakan variabel yang lebih berpengaruh terhadap kepuasan pembaca detikcom. Tingkat kepuasan pembaca detikcom dalam penelitian ini sebesar $74,23 \%$.

\section{Ucapan Terimakasih}

Ucapan terimakasih ditunjukan kepada dosen pembimbing bapak Dr. Rezi Erdiansyah, M.Si., yang telah banyak membantu dan membimbing selama proses penelitian ini berlangsung sampai dengan pembuatan artikel jurnal ini. 
Elsa Susanto, Rezi Erdiansyah: Pengaruh Motif Penggunaan Media dan Kualitas Informasi Terhadap Kepuasan Pembaca Detikcom

\section{Daftar Pustaka}

Ahmadi dan Hermawan. (2013). E-Business \& E-Commerce. Yogyakarta: Andi. . (2015). Strategi Pemasaran (Edisi 4). Yogyakarta: Andi.Ardianto,

Karlinah, \& Komala. (2005). Komunikasi Massa Suatu Pengantar, Cetakan kedua. Bandung: Simbiosa.

Assauri, Sofjan. (2012). Strategic Marketing (Cetakan satu, Edisi 1). Depok: RajaGrafindo Persada.

Azeharie, S., \& Kusuma. (2014). Analisis Pengunaan Twitter Sebagai Media Komunikasi Selebritis di Jakarta. Jakarta: Universitas Tarumanagara.

Gerungan. (2009). Psikologi Sosial. Bandung: PT Refika Aditama.

Ghozali, Imam. (2012). Aplikasi Analisis Multivariate dengan Program IBM SPSS. Yogyakarta: Universitas Diponegoro

Husein, Umar. (2005). Metode Penelitian. Jakarta: Salemba Empat.

McQuail, Dennis. (1991). Teori Komunikasi Massa. Jakarta : Erlangga.

Nisfiannoor. (2013). Pendekatan Statistika Modern Aplikasi Dengan Software SPSS dan E-Views. Jakarta: Universitas Trisakti.

O'Brien, James. (2005). Pengantar Sistem Informasi Perspektif Bisnis dan Manajerial. Jakarta: Salemba Empat

Sugiyono. (2013). Metodelogi Penelitian Kuantitatif, Kualitatif, dan R\&D. Bandung: Alfabeta

Sutabri, Tata. (2012). Analisis Sistem Informasi. Yogyakarta : Andi.

Tjiptono, Fandy. (2012). Strategi Pemasaran (Edisi 3). Yogyakarta: Andi. https://www.alexa.com/siteinfo/detik.com https://kbbi.kemdikbud.go.id/ entri/daring 